9. Шубалий О. М. Економічна статистика. Навчальний посібник. Луцьк: ЛНТУ, 2010.

10. Як змінився ринок праці в Україні. «Роботодавець». URL: https://robotodavets.org.ua/2018/12/12/yakzminyvsya-rynok-pratsi-v-ukrayini.html

\title{
References
}

1. Baranyk Z. P. (2007) Funkcionuvannja rynku praci: statystychna ocinka [Labor market functioning: statistical evaluation]: monoghrafija. Kyjiv: KNEU. 387. [in Ukraine].

2. Begun S. I. (2016) Zastosuvannja klasternogho analizu dlja doslidzhennja demoghrafichnoji sytuaciji u reghioni. [Using cluster analysis for the research of the demographic situation in regione]. Ekonomichnyj chasopys Skhidnojevropejsjkogho nacionaljnogho universytetu imeni Lesi Ukrajinky. 2016. 2 (6). 122-128 [in Ukraine].

3. Kvasha O. S. (2018) Rynok praci v Ukrajini: analiz suchasnogho stanu ta perspektyvy rozvytku [Labor market in ukraine: analysis of the modern state and prospect of development]. Ghlobaljni ta nacionaljni problemy ekonomiky. Vypusk 22. 1074-1079 [in Ukraine].

4. Kykosh Ju. V. (2018) Systema statystychnykh pokaznykiv intensyvnosti ekonomichnoji aktyvnosti naselennja vsikh rivniv osvity [The system of statistical indicators of the intensity of economic activity of the population with different levels of education]. Ekonomichna nauka. Retrieved from: http://www.economy.in.ua/pdf/1_2018/26.pdf [in Ukraine].

5. The Main Directorate of Statistics in Volyn Regiont. (2019) Retrieved fromhttp://www.lutsk.ukrstat.gov.ua [in Ukraine].

6. State Statistics Service of Ukraine. (2019) Mode of access htth://www.ukrstat.gov.ua [in Ukraine].

7. Turin process 2016. (2016) Ukraine. Regional level. Analysis of the system of vocational education of the Volyn region. Project of the European Foundation for Education "Turin Process 2016-17". Ministry of Education and Science of Ukraine, European Education Fund. Kyjiv: «Vik prynt». 99 [in Ukraine].

8. Cherchyk L.M. (2010) Osnovni tendenciji rozvytku molodizhnogho seghmentu rynku praci Volynsjkoji oblasti ta ocinka dijevosti mekhanizmiv derzhavnogho reghuljuvannja zajnjatosti molodi [The main tendencies of development of the youth segm]. Zbirnyk naukovykh pracj. Ekonomichni nauky. Serija «Reghionaljna ekonomika». Vyp. 7 (27). Ch. 5. Lucjk: LNTU. 320-338 [in Ukraine].

9. Shubalyj O. M. Ekonomichna statystyka. [Economic statistics]/ Navchaljnyj posibnyk. Lucjk: LNTU, 2010 [in Ukraine].

10. How the labor market in Ukraine has changed. (2018) Robotodavecj. Retrieved from https://robotodavets.org.ua/2018/12/12/yak-zminyvsya-rynok-pratsi-v-ukrayini.html [in Ukraine].

Стаття надійшла до редакції 03.10.2019 р.

УДК657:004.9]:334.72-057.17

Kulynych Myroslava,

Ph.D. in Economics. Associate Professor of Accounting and Audit Department,

Lesya Ukrainka Eastern European National University, Lutsk, ORCID ID 0000-0001-9024-2924, e-mail: kulmiros@gmail.com

Shepelyuk Nataliya applicant of education, Lesya Ukrainka East European National University, Lutsk, ORCID ID 0000-0001-7732-4837 e-mail: shepelyuk41@gmail.com

https://doi.org/10.29038/2411-4014-2019-04-189-197 


\section{USE OF DIGITAL TECHNOLOGIES IN THE FORMATION OF ACCOUNTING AND ANALYTICAL INFORMATION BY ENTERPRISE MANAGERS}

Due to the dynamic development of accounting, there is a process of active integration of traditional methods of accounting, analysis, control and audit with managerial techniques in a single analytical and accounting system of data acquisition and processing. The importance of accounting and analytical information in making science-based management decisions in a fast-changing external environment, uncertainty in the behavior of economic entities of the market significantly increases and depends on the quality of accounting and reporting space, that is provided by using digital technologies. The integrated accounting and analytical management system of financial and economic activities, which has a «synergistic effect», will make it possible to manage business successfully on a full scale, form a general data base, which provides the process of decision-making.

Keywords: principles of accounting and analysis system, «synergistic effect», a systematicapproach, function, elements of accounting and analysis system: accounting, controland auditing, management decisions.

Кулинич Мирослава, кандидат экономических наук, доцент, Восточноевропейский национальный университет имени Леси Украинки кафедра учета и аудита, г. Луцк

Шепелюк Наталья, соискатель образования,

Восточноевропейский национальный университет имени Леси Украинки, г. Луцк

\section{ИСПОЛЬЗОВАНИЕ ЦИФРОВЫХ ТЕХНОЛОГИЙ В ФОРМИРОВАНИИ УЧЕТНО- АНАЛИТИЧЕСКОЙ ИНФОРМАЦИИ МЕНЕДЖЕРАМИ ПРЕДПРИЯТИЯ}

В условиях динамичного развития бухгалтерского учета проходит процесс активной интеграции традиционных методов учета, анализа, контроля и аудита методами менеджмента в единую учетноаналитическую систему получения данных и обработки информации.Значимость учетно-аналитической информации при принятии обоснованных управленческих решений в условиях быстро меняющейся внешней среды, неопределенности поведения хозяйствующих субъектов рынка существенно возрастает и зависит от качества учетно-отчетного пространства, обеспечивается посредством использования цифровых технологий.Построение комплексной учетно-аналитической системы управления финансово-хозяйственной деятельностью, имеет «синергетические свойства», даст возможность успешно управлять предприятием в полном масштабе, сформировать единую информационную базу, на которой основывается процесс принятия управленческих решений.

Ключевые слова: учетно-аналитическая система, «синергетический эффект», системный подход, функции, элементы учетно-аналитической системы: учет, контроль и аудит, управленческие решения, цифровые технологии.

Кулинич Мирослава кандидат економічних наук, доцент, Східносвропейський національний університет імені Лесі Українки, кафедра обліку і аудиту, м. Луцьк

Шепелюк Наталія здобувач освіти,

Східноєвропейський національний університет імені Лесі Українки, м. Луцьк 


\section{ВИКОРИСТАННЯ ЦИФРОВИХ ТЕХНОЛОГІЙ У ФОРМУВАННІ ОБЛІКОВО- АНАЛІТИЧНОЇ ІНФОРМАЦЇ̈ МЕНЕДЖЕРАМИ ПІДПРИСМСТВА}

В умовах динамічного розвитку бухгалтерського обліку проходить процес активної інтеграції традиційних методів обліку, аналізу, контролю та аудиту з методами менеджменту в єдину обліковоаналітичну систему отримання даних та обробки інформації.

Метою дослідження $\epsilon$ наукове обгрунтування теоретичних гіпотез і принципів формування обліковоаналітичної інформації в системі управління підприємством. У статті наводиться авторська концепція побудови обліково-аналітичного забезпечення системиуправління підприємством в розрізі звітної, аналітичної та контрольної складових, що враховує принцип системності і отримання «синергетичного ефекту». Така система дозволить зробити облікові і аналітичні процеси керованими, сприятиме забезпеченню безперервності об'єднання облікових і аналітичних операцій в один процес, проведення управлінського аналізу, аудиту та використання їх результатів для прийняття управлінських рішень, а також зможе позитивно впливати на формування якості підсумкової обліково-аналітичної інформації та прийнятих управлінськихрішень. Значимість обліково-аналітичної інформації при прийнятті обгрунтованих управлінських рішень в умовах швидко мінливого зовнішнього середовища, невизначеності поведінки господарюючих суб'єктів ринку істотно зростає і залежить від якості обліково-звітного простору, що забезпечується за допомогою використання цифрових технологій.

Побудова комплексної обліково-аналітичної системи управління фінансово-господарською діяльністю, яка має «синергетичні властивості»,дасть можливість успішно управляти підприємством в повному масштабі, сформувати єдину інформаційну базу, на якій грунтується процес прийняття управлінських рішень.

Ключові слова: обліково-аналітична система, «синергетичний ефект», системний підхід, функції, елементи обліково-аналітичної системи:облік, контроль і аудит, управлінські рішення, цифрові технології.

Problem statement and its significance. Modern economic relations in which businesses operate, urgently require the use of effective management technologies of information analysis, which contribute to maintaining their financial stability and solvency. In such a situation, the decision making, both tactical and strategic, should be based on the reliability of the operational information in the necessary analytical sections, which the traditional accounting system cannot fully provide. It is effective to use digital technologies to analyze the accounting and analytical information of an enterprise by its managers, whose research is devoted to this article.

Analysis of recent research and publications. The oretical and practical issues related to the use of digital technologies in management practice are quite widely covered in the works of many foreign (T. Meior, I. Stikul, A. Koberna) and Ukrainian scientists (Z. Varnalii, M. Makedonskiy, M. Matveev, Yu. Petrov, Yu. Rumyantsev, A. Matvienko). However, in spite of the wide range of research into the possibilities of implementing such technologies in business activities, insufficient attention is paid to the problems associated with specific steps in implementing modern digital technologies in enterprise management practices, in particular in accounting. Therefore, systematization of specific technologies and the possibilities of their application in processing accounting and analytical information in the process of enterprise management in modern conditions are becoming especially in demand.

The purpose and objectives of the article. The purpose of this article is to investigate the use of accounting and analytical information by managers to make informed decisions and improve the management of the enterprise by forming its accounting and analytical system with synergistic effect through the introduction of digital technologies.

Presentation of the basic material and substantiation of the results of the research. Making sound management decisions should be based on adequate accounting and analytical support. Accounting and analytical support allows you to effectively implement the basic management functions, which understand the separate areas of management, which differ in the types and amounts of management work, as well as the timing of their implementation.

The specific content and consistency of these types of management activities is defined by different authors ambiguously, but the main management functions are defined by such interrelated elements (stages, blocks of a single management process) - accounting and reporting, control and regulation, analysis and planning, which are a process of continuous, interconnected actions, and form a closed loop. 


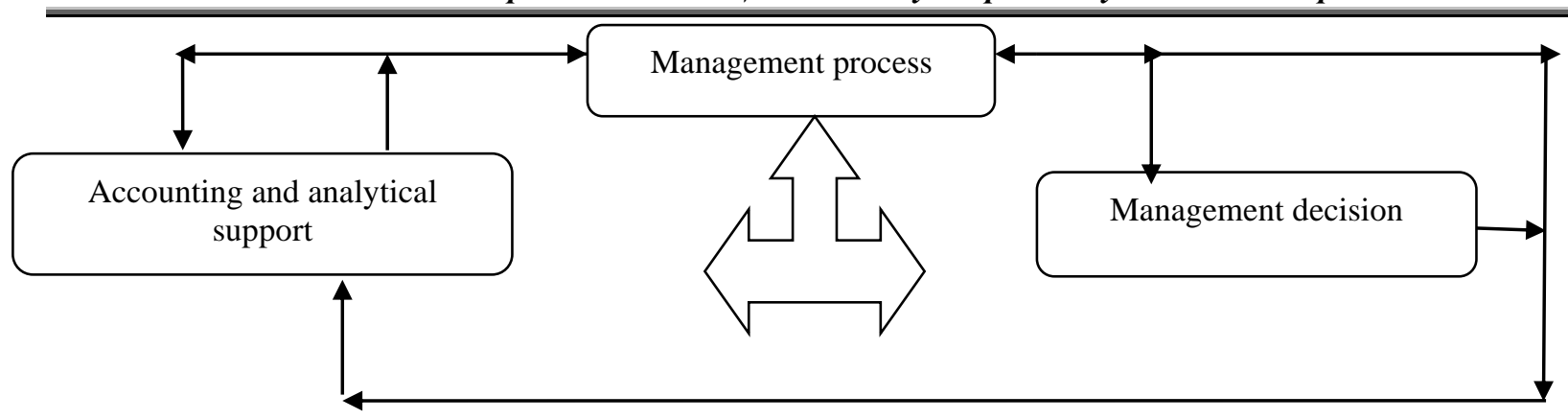

Fig.1 The place of accounting and analytical support in the enterprise management system [1]

Big data, machine learning, distributed registries, robotics, smart things, virtual and augmented reality, wireless, and more, including those that are still being discussed are based on the unconditional and largescale use of digital datasets, determine our immediate and distant future today [1].

The World Bank's 2016 Global Development Report on Digital Technology identifies three mechanisms for influencing companies, the public and the government -

integration, competition and innovation. For companies, this is manifested in trade expansion, as barriers between countries are broken and all companies, regardless of their size, gain access to the global trading market. The use of the Internet and digital technologies reduces the time to search for quality information, reduces transaction costs to almost zero, which significantly increases productivity and capital efficiency. The availability of product price information compels companies to compete for customers, introducing ever new innovations, which contributes to increasing the efficiency of all business processes and creating value [2].

Talking about the digital economy, it should be understood that «this is a new form of business aimed at changing the model of economic management - from program-targeted to program-forecasting - implies a change in economic style, a change in traditional markets, social relations, public administration, related to the penetration of digital technologies in them»[3, p. 4].

The technical possibilities for implementing various solutions in the field of information systems construction are now extremely wide and quite accessible. A growing number of manufacturers are supporting their systems on different platforms and are guaranteeing connections to systems of different devices. Today it is possible to connect to the company's local network at any time. The supervisor can control the work of the subordinate from anywhere in real time.

An important element of the information system of a modern enterprise is IT infrastructure. It is the only complex of software, technical, communication, information and organizational-technological means of ensuring the functioning of the enterprise, as well as the means of managing them.

To be effective, modern enterprises need an IT infrastructure consisting of an integrated set of systems, programs and services. The IT infrastructure should be holistic, as reliable as possible, properly designed, with a large margin of safety, not only to match the current state of the business, but also to take into account its future development.It is for the "proper design" of the IT infrastructure to create an IT strategy, which is a complex of system solutions aimed at long-term improvement of technological and technical components of the enterprise information system.

Information technology and systems (IT / C) is above all a management tool. Like any other, it serves to coordinate and monitor the progress of business processes in achieving goals. Simply owning this tool, like any other tool, does not guarantee success, but its lack of growth-oriented enterprise can lead to a loss of competitiveness, reduced market share and poor efficiency.

When virtually any query can be fulfilled, the key task in creating relevant and effective information systems is to clearly present the necessary result.

Business automation is important for financial accounting and analysis, accounting and supporting documentation. The use of information, innovation systems in this field can significantly increase the competitiveness of the enterprise in the market, as well as identify and neutralize existing problems.

A comprehensive solution to this problem can be found with Enterprise Resource Planning (ERP) systems. In the domestic market, the most popular are software products such as "1C", "Galaxy", "Sail", "SAP" and "Navision". But due to the lack of flexibility and adaptability of Galaxy, Navision and Sail, as 
well as the high cost of both licenses and SAP services, 1C was the most widely used. Also, 1C features that enable the company to consolidate its leadership in the post-market ERP market are reasonable in price, taking into account domestic legislative features, wide functionality and a franchise system that provides a large number of specialists (1C programmers) [4].

It should be noted that the choice of ERP-system requires a thorough analysis of the enterprise, because there is a wide range of configurations that provide automation according to the industry, the specifics of activity, scale, priorities and technologies of the enterprise. The ability to integrate with other services and software ensures the integrity and efficiency of enterprise management.

A new direction of development of modern ERP software is the development of convenient mobile applications that help in the mobile accounting of finances and the maintenance of documentation. Information systems of this type include software tools such as Mint.com (provides not only financial accounting but also a powerful security system), Financisto, Toshl.The peculiarity of "Toshl" is its design: in a humorous style, the application reminds you of budget overruns and provides tips for optimizing their costs [5]. All three of these tools are free. You can also use other apps for a moderate fee. Yes, the advantages of Money, which is one of the most popular in the world among analogues, is not only illustrative of the movement of money through infographics, but also the ability to support transactions with checks and voice comments. An application such as BilliBox does not require mechanical entry of information, as only photographs of checks from which it "pulls" all the necessary information are sufficient.

Interesting in streamlining the financial management process are the free DebtControl and BillMinder applications that help control payables through a reminder system and prioritize payment directions [6].

Digital transformation of a business can be realized provided the creation of a certain material and telecommunications base, software, information products for the development, storage, transmission and receipt of digital information; training staff to work with these products and actively use them in their professional activities. At the enterprise level, this is done through the formation or restructuring of its accounting and analytical system using digital technologies.

If we consider the synergistic effect in the context of financial and economic activities, then we can imagine it as a resultant effect, which is manifested in the significant increaseefficiency of business activities in the process of interaction, integration, merging of disparate processes into a powerful, coherent system.

In view of this, the construction of a comprehensive accounting and analytical system of business management that has "synergistic properties" will allow managers to successfully manage the enterprise on a full scale, to form a single information base on which the decision-making process of management is based.

Therefore, in our view, the development and implementation of methodologically sound management accounting and control systems based on digital technologies will provide invaluable assistance to managers in the process of business planning and management of business processes.

Accounting and analytical system is a complex system, a set of interrelated and separate subsystems: accounting, analytical and audit (Fig. 2). It is based on both accounting and non-accounting information, which allows for the day-to-day, operational and strategic management of the organization.

As can be seen from Fig. 2, the management accounting and analytical system is the foundation, the foundation by which top and middle level managers make management decisions. Therefore, this system is necessary, first of all, for the collection and qualitative processing of special methods and techniques of accounting and analysis of information, which is required for making operational, tactical and strategic decisions and monitoring them.

It is the accounting and analytical system "responsible" for the organizationaccounting on the enterprise, the implementation of internal control and audit, analysis. Management accounting system uses accounting methods: documentation, evaluation, calculation, balance sheet, accounts and double entry, reporting, inventory, methodological basis of management analysis, as well as the necessary audit procedures. 


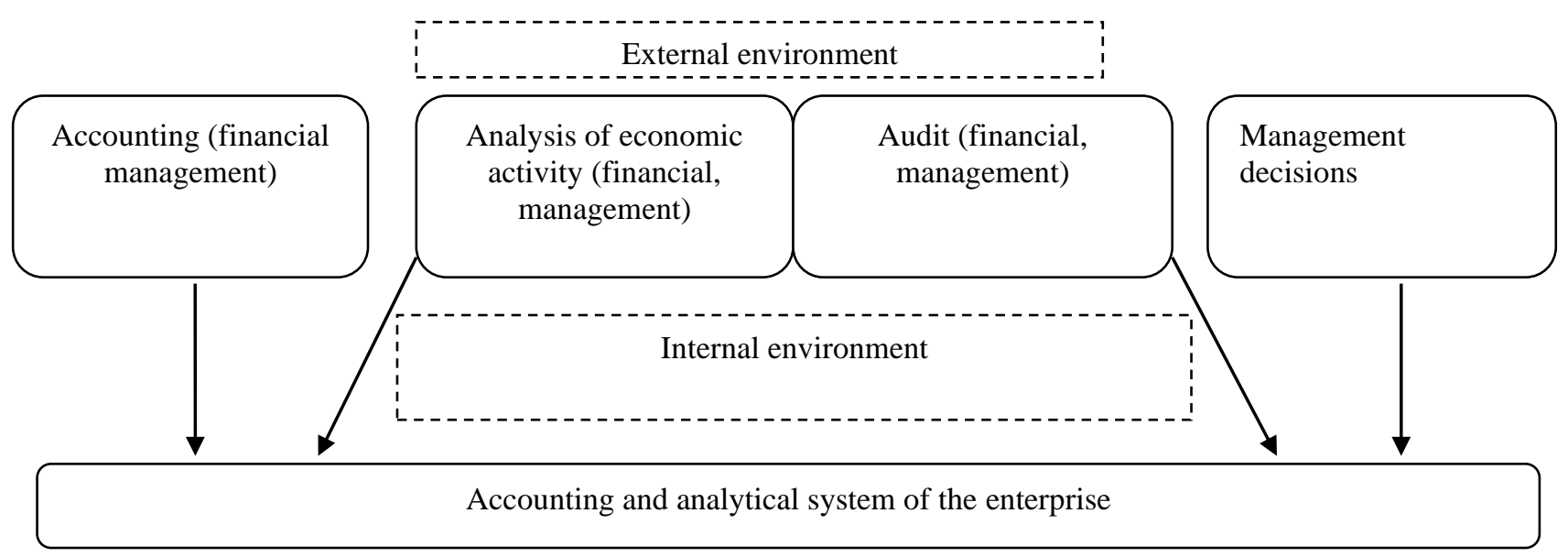

Fig.2 Scheme of interrelation of elements of accounting and analytical system of the enterprise*

* Source: (authors' own development).

Accounting information should be timely, accurate, objective, analytical, qualitatively processed and evaluated, as it is based on it: analysis of the economic activity of the enterprise, showing how effective its activity for a certain (reporting) period; auditing of financial statements; the rationale for making certain decisions by management.

Thus, the above main interrelated elements (accounting, analysis and audit), which are the functions of enterprise management and have common goals, are combined into a single accounting and analytical system.

The purpose of accounting and analytical system as one of the components of the general management system, first of all - in the synergy (integration) of accounting and analytical operations into one continuous process, conducting management analysis and using its results to make tactical and strategic management decisions. In other words, there is an active integration of accounting, analysis, audit and control, since one cannot exist without the other.

We believe that for more efficient organization of accounting and analytical system should streamline the documentation, automate the processing of information, its search, why directly depends on the success and effectiveness of the enterprise, as well as reduce the timing of decision making, which will significantly improve the management system. On this basis, we propose the author's concept of accounting and analytical system of management of a commercial organization (Fig. 3).

In our view, the key to enabling the accounting and analytical system to achieve its goals is the continuity of the interconnected operation of its components: accounting, analysis and audit, which is achieved through the use of digital technologies.

Summarizing the above, we note that each of the formulated principles, even taken separately, in its practical implementation can have some effect. But the effect increases if they are used in combination, in synergy. Then these principles are transformed into a certain decision-making system that is capable and ready to accomplish its tasks clearly and effectively manage the enterprise.

Blockchain (blockchain) is a distributed database in which enterprise storage devices are not connected to a shared server, that is, such a database is decentralized. It keeps an ever-growing list of ordered entries called blocks. Blockchain is not only a decentralized storage system but also a digital register of transactions, transactions, contracts. Consists of a set of records. The main difference and the undeniable advantage is that this registry is not stored in one place. It is distributed among hundreds and even thousands of computers worldwide. Any user of this network can have free access to the current version of the registry, which makes it transparent to all contemporaries [7].

Blockchain works as follows: all transactions are combined into "blocks" by means of complex mathematical algorithms, which are then linked cryptographically and chronologically into a "chain" and have a certain hash (digital password) of the previous block. The transaction is only carried out when it is considered confirmed [8]. 


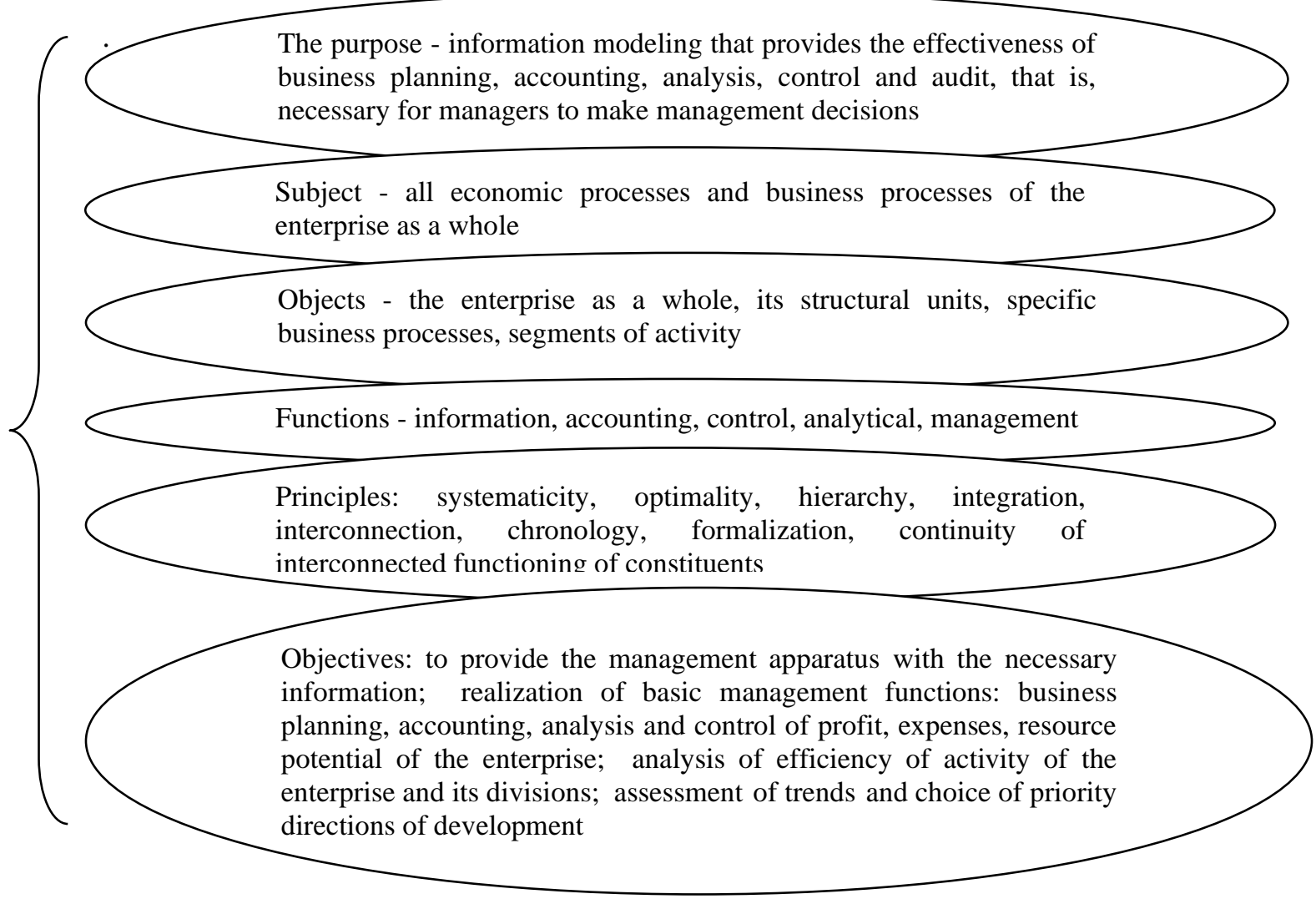

Fig. 3 The concept of enterprise accounting and analytical system*

* Source: (authors' own development).

This is convenient and reliable when it comes to making payments or transferring sensitive information. For cryptocurrency transactions, for example, the blockchain contains information about all Bitcoin transactions ever performed.

A large number of computers that work on the same network have the hash of encryption. Each block is linked to the previous one and contains a set of records. Each block has its own unique hash. All transactions are online [9]. New blocks are always added to the end of the chain. If as a result of their calculations they all get the same result, then the block is assigned a unique digital signature (signature). Once the registry is updated and a new block is created, it can no longer be modified. Thus, it is impossible to forge it. You can only add new entries to it. It is important to keep in mind that the registry is updated on all computers on the network at the same time. Thus, one of the benefits of blockchain is that hacking is not possible because you need to have access to databases on all computers at the same time. The hashing process is irreversible and even if the document is modified, it will receive a different digital signature, which will signal a system mismatch.

Blockchain is a specific way of writing data similar to archives in Excel. But all records are made not in one place, but everywhere: on the network and on all computers of the participants of creation and modification of this block, which cannot be accessible to anyone without permission. This allows all participants to protect the integrity of the document.The main benefits of using blockchain are:

- removal of the mediator. The principle behind the operation of blocks is that it allows transactions to be verified without human intervention, that is, a proxy that minimizes the risk of error. According to this principle, the so-called "reasonable contracts" are concluded automatically, in accordance with predefined rules. Completion of a transaction is indicated by an event or actions that may take the form of a date, amount or authorization given by a certain number of elected representatives.

- cost reduction. Investment banks can improve their back office while reducing costs. Forty-five banks, including BNP Paribas and Société Générale, have teamed up with the R3 CEV project to implement 
interconnected blockchains to replace existing data logging systems. Today's interbank exchanges are managed by Swift's platform or by clearing institutions such as Clearstream [10].

- security. The irreversibility of the chain created and the ability to validate it also give clear benefits to participants in the creation and modification of the block and all stakeholders.

The main risk to blockchain and bitcoin is the dependence on fluctuations in the number of active users, and the number of businesses that use bitcoin as a payment method. [11]. drugs [12].

Blockchain not only allows cryptocurrencies to function but also to create any other service. In general, blockchain technologies can be used in various fields: cyber security, education, sales and leasing of machines and upgrade services for listening to music online.

Conclusions and prospects for further research. Accounting and analytical support of economic entities allows you to effectively implement the basic management functions, which understand the separate areas of management, which differ in types and amounts of management work, as well as the timing of their implementation.

In the financial crisis, accounting and analytical support for the process of management of business entities and methods for its improvement through digital technology is one of the determining factors for improving the efficiency of their activities.

Depending on the goals of the long-term development of the enterprise and the strategy for their achievement, as well as the information needs of managers of different levels and areas, the construction of accounting systems in different businesses has its own characteristics and requires the use of various digital technologies. In particular, automation of business processes of the enterprise, introduction of electronic document flow and electronic filing of reports, creation of virtual workplaces of the enterprise, etc. by means of blockchain.

Blockchain makes data transfer faster, safer and cheaper. In addition, blockchain provides data security, acts automatically, eliminating the need for intermediaries, and thus reduces the risk of human error. In this transparent database, data is protected against manipulation, alteration or breaking of blocks of blockchain, as this would require the control of all computers operating on the network by the superstructure of blocks and chains. However, there are risks: manipulation of fraudulent transactions to deceive the system will be possible, but complex, in addition, in the context of crypto currency, blockchain and bitcoin are dependent on fluctuations in the number of active users, and the number of businesses that use Bitcoin as a payment method.But in general, blockchain is an extremely revolutionary phenomenon. The principle of blockchain will allow to develop not only the banking sector but also others, in particular, medicine, education, business, protection of people from fraudulent schemes and manipulations, so it has a great future, especially in Ukraine.

The accounting and analytical system at the enterprise is organized to provide external and internal consumers with information sufficient to make effective management decisions in the uncertain environment of the competitive environment. This requires identification of information needs in order to establish specific requirements of users of accounting and reporting information, inclusion in the process of forming a management system accounting space and improvement of the feedback mechanism, the speed and completeness of which reaches I'm using IT technologies. Satisfaction of users of accounting information, in our opinion, should be considered as an important factor in the system of motivation of accounting employees and as one of the main indicators of efficiency and effectiveness of accounting and analytical system of a business entity.

\section{Sources and literature}

1. Цифрова економіка. Глобальні зміни на основі нових цифрових технологій та інноваційних бізнесмоделей. ФЦП (лого) Фонд «Цифрові Платформи» Цифрова економіка Глобальні зміни на основі нових цифрових технологій та інноваційних бізнес-моделей. [Електронний ресурc]. URL: http://fidp.ru/ research / digital.

2. Всесвітній банк. 2016 рік. Доповідь про світовий розвиток 2016 «Цифрові дивіденди». Огляд. Всесвітній банк / Вашингтон, округ Колумбія. Ліцензія: Creative Commons Attribution CC BY 3.0 IGO. Open Knowledge Repository. [Електронний ресурc]. URL: https://openknowledge.worldbank.org/.

3. Черненко В.А. Финансовая система в условиях формирования цифровой экономики: коллективная монография. - СПб: Изд-во СПбГЕУ, 2018. - 119 с. 
4. Конкуренти і альтернатива 1C [Електронний ресурс]. - Режим доступу: http://programmist1s.ru/est-lianalog-1s

5. 10 мобільних додатків, які контролюють особисті фінанси [Електронний ресурс]. - Режим доступу: http: // qps. ru / 5qJOP

6. 10 кращих програм квітня для iPhone [Електронний ресурс]. - Режим доступу: http://lifehacker.ru/2015/04/30/best-apps-for-iphone-april

7. What is Blockchain Technology? A Step_by_Step Guide For Beginners [Електронний ресурс]. — Режим доступу: https://blockgeeks.com/guides/what_is_blockchain_technology/

8. What is Blockchain Technology? [Електронний ресурc]. - Режим доступу: http://www.coindesk.com/ information/what_is_blockchain_technology/

9. What is a blockchain, and why is it growing in popularity? [Електронний ресурс]. - Режим доступу: https://arstechnica.com/information_technology/2016//what_is_blockchain/

10. A chain of opportunities for blockchain [Електронний pecypc]. - Режим доступу: http://capgemini.ft.com/ trend_checking/a_chain_of_opportuni ti es_for_blockchain_f_55.html?mhq5j=e1

11. Cryptomonedas: riesgos y oportunidades (II) ? [Електронний ресурс]. — Режим доступу: http://blogs. elconfidencial.com/mercados/aprender_a_invertir/2016_12_09/cryptomonedas_riesgos_oportunidades_inversion_1301 092/

12. El bitcoin sigue dando de qu? hablar [Електронний ресурc]. — Режим доступу: https:/ /criptonot icias.com/opinion/el_bitcoin_sigue_dando_de_que_hablar/\#axzz4m

\section{References}

1. The digital economy. Global change based on new digital technologies and innovative business models. Digital Platform Global Changes Based on New Digital Technologies and Innovative Business Models. [Electronic resource]. URL: http://fidp.ru/ research / digital. [in Ukrainian].

2. The World Bank 2016. 2016 World Digital Development Report Digital Dividends. Review. World Bank / Washington, DC. License: Creative Commons Attribution CC BY 3.0 IGO. Open Knowledge Repository. [Electronic resource]. URL: https://openknowledge.worldbank.org/. [in Ukrainian].

3. Chernenko VA (2018) Finansovaya sistema v usloviyakh formirovaniya tsifrovoy ekonomiki: kollektivnaya monografiya [The financial system in the conditions offormation of the digital economy: a collective monograph] SPb. [in Russian].

4. Competitors and Alternative 1C [Electronic resource]. - Access mode: http://programmist1s.ru/est-li-analog1s. [in Ukrainian].

5. 10 mobile applications that control personal finances [Electronic resource]. - Access mode: http: // qps. / 5qJOP. [in Ukrainian].

6. Top 10 April Apps for the iPhone [Online Resource]. - Access Mode: http://lifehacker.ru/2015/04/30/bestapps-for-iphone-april [in Ukrainian].

7. What is Blockchain Technology? A Step_by_Step Guide For Beginners [Electronic resource]. - Access mode: https://blockgeeks.com/guides/what_is_blockchain_technology/[in English].

8. What is Blockchain Technology? [Electronic resource]. - Access mode: http://www.coindesk.com/ information/what_is_blockchain_technology/[in English].

9. What is a blockchain, and why is it growing in popularity? [Electronic resource]. - Access mode: https://arstechnica.com/information technology/2016//what is blockchain/ [in English].

10. A chain of opportunities for blockchain [Electronic resource]. - Access mode: http://capgemini.ft.com/ trend_checking/a_chain_of_opportuni ti es_for_blockchain_f_55.html?mhq5j=e1[in English].

11. Cryptomonedas: riesgos y oportunidades (II) ? [Electronic resource]. - Access mode: http://blogs. elconfidencial.com/mercados/aprender_a_invertir/2016_12_09/cryptomonedas_riesgos_oportunidades_inversion_1301 092/[in English].

12. El bitcoin sigue dando de qu? hablar [Electronic resource]. - Access mode: https:/ /criptonot icias.com/opinion/el_bitcoin_sigue_dando_de_que_hablar/\#axzz4m_. [in English].

Стаття надійшла до редакції 08.10.2019 р. 